\title{
A Forkhead box G1 (FOXG1) gene mutation in an Indian patient with a congenital variant of Rett syndrome.
}

\author{
Dudipala S. ${ }^{1 *}$, Reddy Cheruku N. ${ }^{2}$, Chaithanya Battu K. ${ }^{3}$ \\ DOI: https://doi.org/10.17511/ijpr.2020.i08.09
}

\footnotetext{
1* Sai Chandar Dudipala, Consultant Pediatric Neurologist, Department of Pediatric Neurology, Star Women and Children Hospital, Karim Nagar, Telangana, India.

2 Naveen Reddy Cheruku, Consultant Pediatrics, Department of Pediatric, Star Women and Children Hospital, Karim Nagar, Telangana, India.

3 Krishna Chaithanya Battu, Diploma in Child Health, Consultant Pediatrician, Star Women and Children Hospital, Karim Nagar, Telangana, India.
}

A congenital variant of rett syndrome or Forkhead box G1 (FOXG1) syndrome is a rare neurodevelopmental disorder characterized by global developmental delay, microcephaly, autistic features, early-onset dyskinesia, and seizures. Once it was described as one atypical variant of rett syndrome but now considered as a separate entity. The current study found one girl carrying the de novo c.500-501incG frameshift mutation in the FOXG1 gene by genetic analysis during the evaluation for severe chronic encephalopathy. In literature, only one case was reported from India with FOXG1 mutation. The FOXG1 mutation should be considered in children with a history of global developmental delay, dyskinesia, and microcephaly with characteristic brain neuroimaging findings.

Keywords: FOXG1, Rett syndrome, Dyskinesia, Microcephaly

Corresponding Author

Sai Chandar Dudipala, Consultant Pediatric Neurologist, Department of Pediatric Neurology, Star Women and Children Hospital, Karim Nagar, Telangana, India.

Email: drsaichander@gmail.com
How to Cite this Article

To Browse

Dudipala SC, Cheruku NR, Battu KC. A Forkhead box G1 (FOXG1) gene mutation in an Indian patient with a congenital variant of Rett syndrome.. Pediatric Rev Int J Pediatr Res. 2020;7(8):442-445.

\section{Available From}

https://pediatrics.medresearch.in/index.php/ijpr/arti cle/view/647

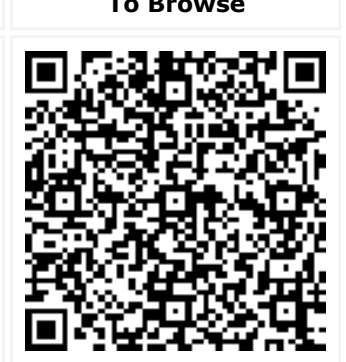

Manuscript Received 2020-11-21

Conflict of Interest No

Review Round 1
2020-12-01
Funding
Nil

Review Round 2 2020-12-10

Ethical Approval Yes
Review Round 3

Plagiarism X-checker $4 \%$
Accepted 2020-12-17

Note () 2020 by Sai Chandar Dudipala, Naveen Reddy Cheruku, Krishna Chaithanya Battu and Published by Siddharth Health
Research and Social Welfare Society. This is an Open Access article licensed under a Creative Commons Attribution 4.0 International License https://creativecommons.org/licenses/by/4.0/ unported [CC BY 4.0]. 


\section{Introduction}

Rett syndrome (RTT) (RTT; OMIM \#312750) is a rare neurodevelopmental disorder usually affecting females, with the prevalence of approximately 1 in $10,000-15,000$ females. RTT is diagnosed based on the consensus clinical criteria $[1,2]$. However, those with several clinical presentations that do not fulfill all the diagnostic criteria are classified as having atypical RTT. Atypical RTT is subclassified into three categories. These categories include a congenital variant, early seizure variant, and preserved speech variant [1]. A congenital variant of RTT (OMIM\#613454) was caused by Forkhead box G1 (FOXG1; OMIM\#164874) gene mutation. Furthermore, delineation of the phenotype associated with mutations in FOXG1 led to the suggestion to consider the FOXG1 syndrome as an entity separate from RTT [3].

Hence, FOXG1 syndrome and Congenital RTT are using interchangeably, but FOXG1 syndrome is preferable. This syndrome is characterized by global developmental delay, microcephaly, severe intellectual disability, early-onset dyskinesia, stereotypic hand movements, and seizures [3,4]. Up to now, fewer than 120 cases have been reported worldwide $[5,6,7]$. The current case study describes a case of FOXG1 syndrome in an infant with severe global developmental delay and early onset movement disorders.

\section{Case History}

A 1-year-old girl born of 3rd degree consanguineous marriage presented to the pediatric neurology clinic with complaints of global developmental delay. Pregnancy and birth history were uneventful with no indication of intrauterine or perinatal hypoxia or other neonatal complications. The child had global developmental delay since early infancy.

At present, the child had partial neck control, no rollover, and not reaching the objects. The child had poor visual fixation and poor response to sound. Seizures were first noted at nine months of age and controlled with medications. The child had stereotypic hand movements and frequent tongue protrusion for two months. Her family history was nil significant for developmental delay or seizures. On examination at one year of age, her head circumference was $41 \mathrm{~cm}$ (<3rd centile), her weight was $9 \mathrm{~kg}$ (50th centile) and her height was $72 \mathrm{~cm}$ (25th centile).
The child had dysmorphic features like synophrys, a hairy forehead, and a pointed chin. Ophthalmological examination revealed poor visual fixation, intermittent nystagmus, and normal fundus. Neurological examination showed no cranial nerve defect, hypotonia, normal deep tendon reflexes, and stereotypic movements of limbs.

On laboratory investigations, complete blood picture, blood sugar, renal function tests, creatinine, thyroid profile, lactate, and vitamin D3 were normal. Tandem mass spectrometry was normal. Her nerve conduction study was normal. Magnetic resonance imaging (MRI) brain revealed subcortical band heterotopia and simple gyral pattern.

After all diagnostic work-up, on the ground of severe progressive encephalopathy and consanguineous parents, genetic etiology was considered. DNA sequencing with next-generation sequencing platform revealed a pathogenic mutation FOXG1 gene which causes an autosomal dominant congenital variant of RTT. Symptomatic treatment and genetic counseling were advised.

\section{Discussion}

FOXG1 syndrome is a rare severe neurodevelopmental disorder that affects both genders. The first case of FOXG1 mutation was reported in 2005 by Shoichet in a female child with global developmental delay and microcephaly [8]. In literature, some case series and cohort studies were reported from various countries [3-7]. Das et al reported the first case of atypical RTT with FOXG1 mutation in 2014 [9]. One more case was reported with atypical rett syndrome with deletion at the $14 q 12$ region [10].

Heterozygous pathogenic variants in FOXG1 cause a severe neurodevelopmental encephalopathy. It is characterized by severe global developmental delay, cognitive impairment, movement disorders, autistic features, and epilepsy. The cardinal feature of this syndrome is an early-onset movement disorder. These movement disorders commonly develop before one year of age. These movement disorders are including choreoathetosis, dystonia, and orolingual/facial dyskinesias, and myoclonic jerk. $[5,11,12]$. Stereotypies are present in $50-87 \%$ of the patients $[6,11,13]$. The hand stereotypies often involve objects and hand-mouthing. Other comorbidities include Sleep disturbances, irritability, inconsolable cry, gastroesophageal reflux, constipation, and breathing abnormalities [3]. 
In the present case child developed choreoathetosis movements, orolingual dyskinesia at 10 months of age.

FOXG1 gene is located on chromosome $14 \mathrm{q} 12$ and belongs to the forkhead (FOX) family of genes. To date, there are more than 120 different mutations, including deletions, intragenic mutations, and duplications, of FOXG1, that have been reported worldwide $[6,13-16]$. FOXG1 plays a determining role in the development of the anterior brain, cortical lamination, and the forming of the corpus callosum [3]. Mitter et al reviewed the genotypephenotype correlation in 83 patients with mutations in FOXG1.

Individuals with truncating mutations have a more severe type and individuals with missense mutations have milder phenotypes. In the present case heterozygous single base pair insertion in exon 1 of the FOXG1 gene that results in a frameshift and premature truncation of the protein 285 amino acids downstream to codon 170 (p.Lys170GInfsTer285) was detected. A similar genotype was reported by Bruyn et al. in a male child [4].

Children with FOXG1 mutations have a spectrum of structural brain anomalies, ranging from corpus callosal abnormalities to frontal pachygyria combined with delayed myelination in its most severe form $[4,13]$. Vegas et al reported various MRI brain patterns in FOXG1 syndrome patients with genotypic delineation [13]. In our case, the child's MRI brain showed subcortical band heterotopias with the simple gyral pattern. Bruyn et al reported different MRI patterns with a similar genotype. At present, there are no therapeutic options are available for the treatment of FOXG1 syndrome. Still rehabilitation therapy, symptomatic therapy is the mainstay of treatment. In the present case, the child was treated with levetiracetam, lansoprazole, and physiotherapy.

\section{Conclusion}

FOXG1 syndrome or a congenital variant of RTT is a rare neurodevelopmental disease with the variable genotype-phenotype presentation. The FOXG1 mutation should be considered in individuals with a history of global developmental delay, early-onset dyskinesia, and microcephaly with characteristic brain images. As of our best knowledge, this is the second reported case with FOXG1 mutation from India.

\section{Reference}

01. Neul JL, Kaufmann WE, Glaze DG, Christodoulou $\mathrm{J}$, Clarke AJ, Bahi-Buisson N, et al. Rett synd rome- revised diagnostic criteria and nome nclature. Annals Neurol. 2010;68(6)944-50.

doi: 10.1002/ana.22124 [Crossref]

02. Kumamoto T, Hanashima C. Evolutionary conservation and conversion of Foxg1 function in brain development. Dev Growth Differ. 2017;59(4)258-269.

doi: $10.1111 /$ dgd.12367 [Crossref]

03. Kortüm F, Das S, Flindt M, Morris-Rosendahl DJ, Stefanova I, Goldstein A, et al. The core FOXG1 syndrome phenotype consists of postnatal microcephaly, severe mental retardation, absent language, dyskinesia, and corpus callosum hypogenesis. J Med Genet. 2011;48(6)396-406. doi: $10.1136 / \mathrm{jmg} .2010 .087528$ [Crossref]

04. De Bruyn C, Vanderhasselt T, Tanyalçin I, Keymolen K, Van Rompaey KL, De Meirleir L, et al. Thin genu of the corpus callosum points to mutation in FOXG1 in a child with acquired microcephaly, trigonocephaly, and intellectual developmental disorder- A case report and review of literature. Eur J Paediatr Neurol. 2014;18(3)420-426.

doi: 10.1016/j.ejpn.2013.11.010 [Crossref]

05. Caporali C, Signorini S, De Giorgis V, Pichiecchio A, Zuffardi O, Orcesi S. Early-onset movement disorder as diagnostic marker in genetic synd romes- Three cases of FOXG1-related syndro me. Eur J Paediatr Neurol. 2018;22(2)336-9. doi: 10.1016/j.ejpn.2018.01.007 [Crossref]

06. Mitter $D$, Pringsheim $M$, Kaulisch $M$, Plümacher KS, Schröder S, Warthemann R, et al. FOXG1 syndrome- Genotype-phenotype association in 83 patients with FOXG1 variants. Genet Med. 2018;20(1)98-108.

doi: $\quad 10.1038 / \mathrm{gim} .2017 .75 \quad$ [Crossref]

07. Zhang Q, Wang J, Li J, Bao X, Zhao Y, Zhang X, et al. Novel FOXG1 mutations in Chinese patients with Rett syndrome or Rett-like mental retardation. BMC Med Genet. 2017;18(1)96.

doi: 10.1186/s12881-017-0455-y [Crossref] 
08. Shoichet SA, Kunde SA, Viertel P, Schell-Apacik C, von Voss $\mathrm{H}$, Tommerup $\mathrm{N}$, et al. Haploinsufficiency of novel FOXG1B variants in a patient with severe mental retardation, brain malformations and microcephaly. Hum Genet. 2005; 117(6)536-544.

doi: $10.1007 / \mathrm{s} 00439-005-1310-3 \quad$ [Crossref]

09. Das DK, Jadhav V, Ghattargi VC, Udani V. Novel mutation in forkhead box G1 (FOXG1) gene in an Indian patient with Rett syndrome. Gene. 2014;538(1)109-112.

doi: $10.1016 /$ j.gene.2013.12.063 [Crossref]

10. Vineeth VS, Dutta UR, Tallapaka K, Bhowmik $A D$, Dalal $A$. Whole exome sequencing identifies a novel $5 \mathrm{Mb}$ deletion at $14 \mathrm{q} 12$ region in a patient with global developmental delay, microcephaly and seizures. Gene. 2018;673;5660.

doi: 10.1016/j.gene.2018.06.045 [Crossref]

11. Papandreou A, Schneider RB, Augustine EF, Ng J, Mankad K, Meyer E, et al. Delineation of the movement disorders associated with FOXG1 mutations. Neurol. 2016;86(19)1794-1800.

doi: $10.1212 /$ WNL.0000000000002585 [Crossref]

12. Cellini $E$, Vignoli $A$, Pisano T, Falchi $M$, Molinaro $A$, Accorsi $P$, et al. The hyperkinetic movement disorder of FOXG1-related epileptic-dyskinetic encephalopathy. Dev Med Child Neurol. 2016;58(1)93-97.

doi: $10.1111 / \mathrm{dmcn} .12894$ [Crossref]
13. Vegas N, Cavallin M, Maillard C, Boddaert N, Toulouse J, Schaefer $E$, et al. Delineating FOXG1 syndrome- From congenital microcephaly to hyperkinetic encephalopathy. Neurol Genet. $2018 ; 4(6) \mathrm{e} 281$.

doi: 10.1212/NXG.0000000000000281 [Crossref]

14. Pontrelli G, Cappelletti S, Claps D, Sirleto P, Ciocca L, Petrocchi $S$, et al. Epilepsy in patients with duplications of chromosome 14 harboring Foxg1. Pediatr Neurol. 2014;50(5)530-535. doi: $10.1016 /$ j.pediatrneurol.2014.01.022 [Crossref]

15. Yeung A, Bruno D, Scheffer IE, Carranza D, Burgess $T$, Slater $H R$, et al. 4,45 $\mathrm{Mb}$ microduplication in chromosome band $14 \mathrm{q} 12$ including FOXG1 in a girl with refractory epilepsy and intellectual impairment. Eur J Med Genet. 2009;52(6)440-442.

doi: 10.1016/j.ejmg.2009.09.004 [Crossref]

16. Seltzer LE, Ma M, Ahmed S, Bertrand M, Dobyns WB, Wheless $\mathrm{J}$, et al. Epilepsy and outcome in FOXG1-related disorders. Epilepsia. 2014;55(8)1292-1300.

doi: $10.1111 /$ epi.12648 [Crossref] 